\title{
Editorial
}

\section{Applying Maritime Economics to Set Foundations for Port and Shipping Policies}

\section{THE FIRST IAME CONFERENCE IN LATIN AMERICA}

As most readers of this journal will know, the International Association of Maritime Economists (IAME) held its Tenth Anniversary Conference in Panama last November. This special edition of MEL features a selection of outstanding papers that were presented during the event. ${ }^{1}$

Under the conference theme 'Maritime Economics - setting the foundations for port and shipping policies', the organisers aimed to encourage papers which are of particular interest to the public sector and policy-makers. Topics such as shipping alliances, the regulation of ports, the economic impact of transport corridors, future intermodal and transshipment patterns, and the relationship between transport costs and trade were considered to be of increasing relevance for policy-makers in Latin America and other regions. It was felt that a meeting of maritime economists under this conference theme would be of mutual interest for researchers and for those dealing with ports and shipping matters in the public sector.

This present special issue of MEL includes some of the most interesting contributions in this regard. The first two papers look at regulatory aspects in shipping and ports, the third and fourth paper deal with trade and transport corridors, and the last two papers analyse the relationship between trade and transport costs. Furthermore, the issue also includes a policy perspective from the Panama Canal and a book review covering Latin America and the Caribbean, thus further contributing to the integration of this region into the world of Maritime Economics and Logistics. In this context, I would like to personally thank MEL and its Editor-in-Chief for their cooperation and full support to this first IAME conference in Latin America from the very outset of its preparation.

\section{THE PAPERS OF THIS SPECIAL EDITION}

The first paper, by Mike Fusillo, looks at the apparently technical topic of excess capacity in liner shipping. His rigorous analysis and the following conclusions, 
however, go far beyond technical choices of a shipping company. Policymakers and international organisations such as the OECD or UNCTAD should be particularly interested in Fusillo's recommendations regarding the need to avoid subsidies, to discontinue the Liner Code of Conduct, and to strictly enforce antitrust rules. This is surely an example where a maritime economist has contributed in setting foundations which help governments in their decision-making processes that are otherwise often at the mercy of 'selective' information provided by interested parties and lobby groups.

The second paper, by Lincoln Flor and Enzo de Felippo, analyses the Peruvian model for regulating access to port infrastructure. The country's main port of Callao is practically holding a monopolistic position, especially in containerised trades, with hardly any inter-port competition. It has, however, sufficient volume to allow for intra-port competition, for which the public regulator has to ensure that potential service providers have access to essential infrastructure. Most major ports in the world face some degree of interport competition; in their case, the obligation to allow potential competitors to use essential infrastructure might discourage private investment in such infrastructure. For many regional ports and especially for those many Small Island States, however, the paper's game theoretical approach constitutes a useful tool to analyse the potential outcomes of alternative actions by the public port authority.

The third paper, by Leigh Boske and John Cuttino, deals with the measurement of economic and transportation impacts of maritime trade. It starts with an overview of the literature and methodology. Thereafter, taking the example of trade between Brazil's Victoria port complex and Houston in the United States, it provides estimates of cumulative economic and transportation impacts, based on the expenditures on individual shipments from origin to destination. What they tell us is basically the story of the process of two sample trades and their transport, those of coffee and steel. As port impact studies appear to be quite advanced, the authors suggest that similar methodologies should be applied to the more complex processes taking place along a trade corridor; just as past studies took the port as a 'Decision Making Unit', the same approach could and should be applied to entire corridors. Such broad approaches are of particular interest if we consider the ongoing negotiations related to the Free Trade Area of the Americas, and also in view of the need to look at transport corridors and their security implications after 11 September 2001.

In the fourth paper, Meifeng Luo and Thomas Grigalunas present some of the results of an extensive research project about a multimodal transportation simulation model for coastal container ports in the United States. The wellillustrated results show how such a simulation tool provides invaluable 
forecasts about the impact of, for example, new port investments or changes in port tariffs, upon the modal transport split of trade, port throughputs, and the outreach of a port's hinterland, with all the obvious implications for policymakers.

The fifth paper, by Inmaculada Martínez-Zarzoso, Leandro GarcíaMenéndez and Celestino Suárez-Burguet, is about a Spanish case study of the impact of transport costs on international trade. The paper actually goes beyond that title, as the authors also analyse the determinants of these transport costs. In a second stage, estimated transport costs are then included in an econometric analysis of Spanish ceramic exports. The authors conclude that higher transport costs significantly deter trade, confirming previous studies, which is clearly relevant for policy-makers who aim to promote a country's competitiveness. They also conclude that distance does not appear to be good proxy for transport costs, which is an important message for trade analysts, who will need to have a careful look at the determinants of transport costs when forecasting international commerce.

In the sixth paper, the authors Ricardo Sanchez, Jan Hoffmann, Alejandro Micco, Georgina Pizzolitto, Martin Sgut and Gordon Wilmsmeier, report on some findings of joint research about Latin American port efficiency. Analysing exports from 19 ports in nine Latin American countries to the United States, regressions generally confirm previous findings about the impact of distance, commodities and other determinants of transport costs. What is new is the attempt to incorporate different measures of port efficiencies into the transport cost equation. The results are relevant for policy-makers as they confirm that port efficiency has a strong bearing on transport costs and trade efficiency. Unlike distance and many other relevant variables, port efficiency can be influenced by public policies, and large differences in that regard still remain in Latin America and the Caribbean.

The Policy Perspective, a speech by Ricaurte Vásquez during the IAME conference, looks at the economic forces in the decision-making process of the Panama Canal Authority. Above all, in my view, it shows that the return of control of the Canal from the United States to Panama has opened new opportunities to take decisions on a commercial basis, to the long-term benefit not only of the Canal's users, but also of the Panamanian economy as a whole. In this context, I would also like to personally thank the Panama Canal Authority for their willingness to host the IAME conference in Panama, thus confirming its long-term perspective and vision concerning the role Maritime Economics is playing for the future of Panama and its Canal.

Finally, a brief review of the book 'Maritime Transport in Latin America and the Caribbean' by Leigh Boske, concludes this special IAME issue of MEL. 


\section{MARITIME ECONOMICS AND LOGISTICS}

What are the areas and directions in the field of maritime economics and logistics that are of most relevance to policy-makers in coming years? Probably, there will be as many views on this as there will be readers of this editorial, and any feedback on the following thoughts will be more than welcome.

In order to produce relevant research, probably the distinction between 'maritime' and other fields of economics will need to be somewhat blurred. Just as there are ever fewer 'maritime nations' (Sletmo, 2002), maritime transport today is but one component of international logistics, whose demand is derived from international trade. Equivalently, on the supply side, there are now many different maritime businesses, as countries tend to specialise in different components of this industry (Kumar and Hoffmann, 2002). In the context of globalisation, international maritime trade is becoming increasingly relevant for development, implying that those who work as 'maritime' researchers find themselves with a growing field of action. I see principally three main areas into which policy-relevant fields of maritime economics could be grouped:

The first such area is related to the environment and other externalities such as safety and security. This is relevant, for example, for international conventions at the IMO, the policies that aim to promote coastal shipping, or the incorporation of environmental standards into port privatisation processes. Very few papers dealt with such topics at IAME Panama 2002. As transport policy has to make choices about investment, subsidies and taxes that affect different transport modes, the economic, environmental and social impacts of maritime transport will need to be estimated, and those estimates need to be incorporated into trade and transport forecasts. A complex task, where those who specialise in ports and shipping need to cooperate with those who know about global warming, road safety or employment.

A second area where I see a growing 'demand' for maritime economists is related to international trade, economic integration and competitiveness. This encompasses the papers of Sanchez et al and Martinez et al in this issue. A rich literature is evolving around this topic, although it appears that it is rather the main stream economists that are entering the field of maritime transport, rather than port and shipping specialists who would be moving into the broader field of international trade economics. An example is Fink et al (2000), from the World Bank's Development Research Group, who caused quite some polemic discussions among maritime economists with their recommendations about liner shipping cartels. International trade models used to take transport for granted, albeit costly, assuming that distance would be a good 'proxy' for 
these transport costs. As Martinez et al in this journal rightly point out, distance is a bad proxy for transport costs. Demand for transport services is a derived demand from trade. Hence, the virtuous cycle between better and less expensive transport services, higher volumes of trade, and thereafter even better transport services due to economies of scale is a topic where port and shipping analysts can make valuable contributions to trade forecasts and transport policies.

A third area of maritime research which increasingly touches upon other fields of economics is the maritime business as such - or rather the different maritime businesses. Whereas, in the past, a 'maritime nation' had its own, sometimes even state-owned, shipping companies, using the national flag, employing seafarers from its own nautical schools and vessels from national shipyards, which were classed, financed and insured by other national companies, today the situation is quite different. For example, those countries who specialise in flag registration mostly came into this business because they were also involved in other off-shore financial businesses. Increased transit and transshipment of cargo allows countries to participate in the port business even without much national trade. Those countries that today build ships also build cars or machinery, but are not necessarily known for long seafaring traditions. To identify comparative advantages in any of these maritime businesses requires complex industry analysis which needs to go beyond the ships and their ports of call.

\section{MARITIME POLICIES}

A next step could be to formulate the above broad areas of research into goals of a maritime policy, and then to see how these areas are related to each other (Figure 1). The goals would thus be:

(a) to reduce environmental and other transport-related externalities;

(b) to promote economic integration and trade competitiveness through better transport services; and

(c) to generate employment and taxable income in the transport business.

Among these different goals there may exist synergies (ie 'overlaps'), or conflicts of interest. An example of a conflict of interest is the reservation of cabotage to nationally flagged vessels. This is usually done to maintain a 'national fleet', creating employment and taxable income. It is, however, detrimental to the promotion of foreign trade because it tends to prevent international vessels that carry the country's exports to make use of 


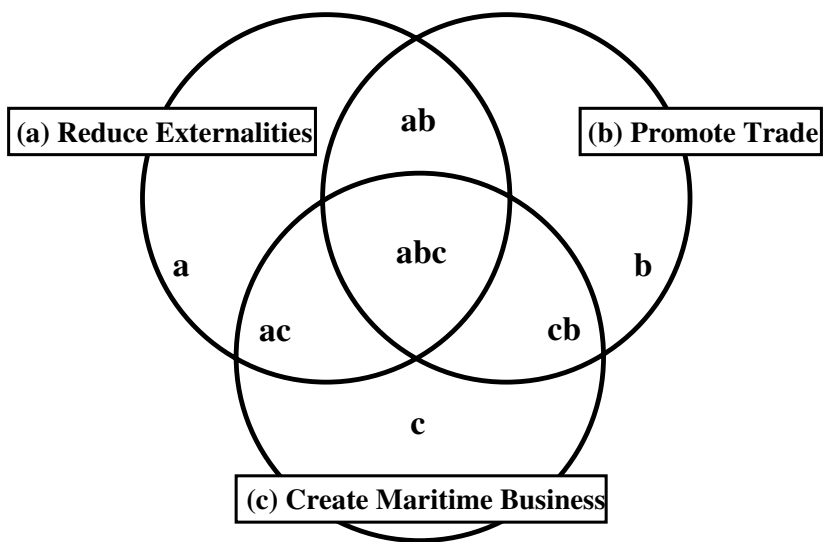

Figure 1: Goals of a maritime policy

spare capacity along the coast. Also, it makes coastal shipping less competitive as compared to the environmentally less desirable truck traffic. Such a situation could be represented by field 'c' in Figure 1. Similarly, one could argue that an example for field 'ac' would be the compulsory introduction of doublehull tankers because it encourages new buildings; and an example of field 'abc' - a win/win/win situation - could be a green field port outside a city, which attracts employment, improves trade efficiency, and reduces congestion and contamination in the old city centre. Further examples are manifold.

As the remainder of this special IAME issue of MEL will show, there exists a very rich and wide area for research in the field of maritime economics and public policies. Such research contributes to set foundations for port and shipping policies, and it provides ample topics for future IAME conferences.

\section{ENDNOTE}

1 The conference took place from 13 to 15 November. It had 240 participants from 35 countries and included 83 presentations of peer-reviewed papers from 159 authors and co-authors, plus 25 further speeches and presentations. The conference was jointly organised by the Panama Canal Authority, City of Knowledge, Panama Maritime Authority, Trainmar Caribbean Network, ULACIT, Panama Chamber of Shipping and the United Nations Economic Commission for Latin America and the Caribbean UN-ECLAC. The members of the international steering committee were Jan Hoffmann (President), Alf Baird, Carlos Martner, Ernst Frankel, Floriano Pires, Heather Leggate, Henriëtte van Niekerk, Hercules Haralambides, John Ricklefs, José Alfredo Sabatino, Kevin Cullinane, Leigh Boske, Martin Sgut, Martin Stopford, Mary Brooks, Olga Bosquez, Raymond Byl, Rodolfo Sabonge, Rodrigo García, Sheila Farrell, Siri Strandenes, Ted Prince, Trevor Heaver and 
William Sjostrom. For the agenda, conference proceedings and further information visit http:// www.eclac.cl/Transporte/perfil/iame_papers/papers.asp.

\section{Jan Hoffmann}

(At the time of writing, until March 2003, UN-ECLAC, Santiago, Chile) United Nations Conference on Trade and Development, UNCTAD, Geneva,

Switzerland. E-mail: JH@JanHoffmann.info

Maritime Economics \& Logistics (2003) 5, 93-99.

doi:10.1057/palgrave.mel.9100072

\section{REFERENCES}

Fink, C, Mattoo, A and Neagu, IC. 2000: Trade in international maritime services: how much does policy matter? Mimeo World Bank: Washington, DC.

Kumar, S and Hoffmann, J. 2002: Globalization, the Maritime Nexus. Handbook of Maritime Economics. LLP: London.

Sletmo, G. 2002: National shipping policy and global markets: a retrospective for the future. IAME Panama 2002 Introductory Speech, Panama, November. 